\title{
PENERAPAN PSAK NOMOR 45 TENTANG PELAPORAN KEUANGAN ORGANISASI NIRLABA PADA SMK NEGERI 1 MANADO
}

\author{
Mario Rantung ${ }^{1}$, Harijanto Sabijono ${ }^{2}$, Victorina Z. Tirayoh ${ }^{3}$ \\ ${ }^{1,2,3}$ Fakultas Ekonomi dan Bisnis, Jurusan Akuntansi, Universitas Sam Ratulangi, Jl. Kampus Bahu, Manado, \\ 95115, Indonesia \\ E-mail: rantungmario@yahoo.co.id
}

\begin{abstract}
Along with the development of the world of education today, the Indonesian government is very serious in responding to the development of education to produce quality schools, this is also with considerable school activities. Things that must be accounted for and delivered through financial statements.This study aims to describe the presentation of financial reports on Nonprofit Organizations and to find out how to implement the application of PSAK number 45 concerning the Presentation of Financial Statements of SMK Negeri 1 Manado. The data research method used is qualitative analysis with qualitative analysis and quantitative analysis. Qualitative analysis to find out the comparative object of research is financial reporting at SMK Negeri 1 Manado with PSAK No. 45 and also with the preparation of budget and budget. Economic analysis to find out the values that arise from the financial statements of SMK Negeri 1 Manado The results of the analysis show that the preparation of financial statements at SMK Negeri 1 Manado has not been used to make financial statements, financial statements, and financial statements that are in accordance with the financial format contained in PSAK No. 45.
\end{abstract}

Keywords: Non-profit organization; PSAK 45

\section{PENDAHULUAN}

Seiring dengan berkembangnya dunia pendidikan saat ini, pemerintah Indonesia sangat serius dalam memperhatikan tingkat perkembangan pendidikan nasional untuk menghasilkan sekolah-sekolah yang berkualitas hal ini juga berkaitan dengan perkembangan kegiatan sekolah yang memerlukan dana yang cukup besar sehingga harus dipertanggungjawabkan penerimaan dan pengeluarannya melalui laporan keuangan. Pendidikan untuk saat ini diibaratkan seperti jembatan untuk meraih sebuah kesuksesan. Nugroho, I (2017) menyatakan bahwa melalui sebuah pendidikan akan menciptakan generasi muda yang mampu untuk menghadapi permasalahan-permasalahan di masa mendatang. Organisasi apapun yang mengelola uang dalam kegiatannya selalu saja harus membuat keputusan yang dipengaruhi oleh kondisi keuangannya, dan juga akan mempengaruhi kondisi keuangan organisasi.

Organisasi nirlaba merupakan suatu organisasi yang bertujuan pokok untuk mendukung kepentingan publik yang tidak komersial, organisasi nirlaba meliputi organisasi keagamaan, sekolah, rumah sakit, dan klinik publik, organisasi masyarakat, organisasi sukarelawan, serikat buruh. Laporan keuangan merupakan sebuah catatan informasi keuangan dalam suatu perusahaan pada suatu periode akuntansi yang dapat digunakan untuk menggambarkan kinerja perusahaan tersebut. Laporan keuangan adalah bagian dari proses pelaporan keuangan.

Tujuan laporan keuangan adalah menyediakan informasi yang menyangkut posisi keuangan, kinerja, serta perubahan posisi keuangan suatu perusahaan yang bermanfaat bagi sejumlah besar pemakai dalam pengambilan keputusan. Laporan keuangan yang disusun untuk tujuan ini memenuhi kebutuhan bersama sebagian besar pemakai. SMK Negeri 1 
Manado merupakan lembaga pendidikian yang bersifat kejuruan. Para lulusan di SMK Negeri 1 Manado sudah diperisapkan untuk dapat terjun langsung dalam dunia kerja. Di dalamnya sudah dibekali keterampilan kejuruan Akuntansi, Sekertaris, Usaha Perjalanan Wisata, Teknik Jaringan Komputer dan Pemasaran.

Sesuai dengan PSAK.45 sekolah SMK Negeri 1 Manado merupakan organisasi nirlaba dan dalam pencatatan laporan keuangan harus menerapkannya. Akan tetapi pada SMK Negeri 1 Manado belum menerapkan pencatatan menurut PSAK.45 tetapi hanya melakukan pencatatan penerimaan kas dan pengeluaran kas saja. Belum adanya pengetahuan tetang pencatatan laporan keuangan yang selayaknya, hanya berasal dari keputusan penanggung jawab dalam penyusunan laporan keuangan berupa laporan pertanggungjawaban penerimaan kas dan pengeluaran kas. Kurangnya pengetahuan mengenai system pencatatan organisasi nirlaba dari sumber daya yang merupakan salah satu faktor dimana SMK Negeri 1 Manado belum menerapkan system pencatat serupa dengan PSAK No. 45.

\section{TINJAUAN PUSTAKA}

Pengertian Akuntansi. Warren \& Reeves (2014) mengatakan bahwa akuntansi dapat diartikan sebagai system informasi yang menyediakan laporan untuk para pemangku kepentingan mengenai aktivitas ekonomi dan kondisi perusahaan. Sistem informasi mengumpulkan dan memproses data-data yang berkaitan dan kemudian menyebarkan informasi keuangan kepada pihak terkait. Dalam pengertian yang lain, akuntansi adalah suatu sistem informasi keuangan, yang bertujuan untuk menghasilkan dan melaporkan informasi yang relevan bagi berbagai pihak yang berkepentingan. Dari definisi diatas maka dapat disimpulkan bahwa akuntansi adalah proses identifikasi, pencatatan, dan pengkomunikasian hasil akhir berupa laporan keuangan yang mencerminkan keadaan perusahaan kepada pihakpihak yang berkepentingan (Hans, 2016).

Organisasi. Jimmy (2014) menyatakan bahwa secara etimologi, organisasi berasal dari bahasa latin organizare, kemudian bahasa inggris organize yang artinya membentuk suatu kumpulan dari bagian-bagian yang berkaitan satu sama lainnya. Jadi, secara sederhananya organisasi adalah wadah/tempat di mana terjadi perkumpulan antara dua orang atau lebih yang ingin bekerja sama secara sistematis dalam sebuah ikatan dan terpimpin dengan tujuan yang sama. Tinungki dan Pusung (2014) organisasi merupakan suatu entitas sosial yang terkoordinasi secara sadar, terdiri dari dua orang atau lebih dengan batasan yang realtif teridentifikasi, yang secara berkelanjutan untuk mencapai seperangkat sasaran bersama. Organisasi terbagi atas dua jenis yaitu organisasi profit (laba) dan non-profit (nirlaba). Januarizal (2011) mendefinisikan:

1. Organisasi profit. Suatu proses kerjasama yang dilakukan oleh sekelompok orang untuk mencapai tujuan bersama yakni untuk menghasilkan laba. Organisasi ini menyediakan atau menghasilkan barang maupun jasa guna untuk memperoleh hasil ataupun laba sesuai dengan keinginan pemilik organisasi tersebut.

2. Organisasi non-profit. Berbeda dengan organisasi profit, tujuan utama dari organisasi ini bukanlah semata-mata untuk mencari laba. Organisasi non profit berdiri untuk mewujudkan perubahan pada individu atau komunitas.

Organisasi nirlaba. Korompis (2014) menyatakan bahwa organisasi nirlaba atau organisasi non profit adalah suatu organisasi yang bersasaran pokok untuk mendukung suatu isu atau perihal di dalam menarik perhatian public untuk suatu tujuan yang tidak komersil, tanpa ada perhatian terhadap hal-hal yang bersifat mencari laba (moneter). Menurut Helen (2017) menyatakan bahwa organisasi nirlaba berbeda dengan organisasi bisnis pada umumnya. Perbedaannya terletak pada cara organisasi tersebut memperoleh sumber daya yang dibutuhkan untuk melakukan berbagai aktivitas operasionalnya. 
Laporan keuangan organisasi nirlaba. Menurut Andarsari (2016:146) Tujuan utama laporan keuangan menurut PSAK No. 45 adalah menyediakan informasi yang relevan untuk memenuhi kepentingan para penyumbang, anggota organisasi, kreditur, dan pihak lain yang menyediakan sumber daya bagi organisasi nirlaba. Munawir (2016:146) mengatakan "Laporan keuangan merupakan alat yang sangat penting untuk memperoleh informasi sehubungan dengan posisi keuangan dan hasil-hasil yang telah dicapai oleh perusahaan yang bersangkutan. Dengan begitu laporan keuangan diharapkan akan membantu bagi para pengguna untuk membuat keputusan ekonomi yang bersifat finansial. Dinanti dan Nugraha (2018) menyatakan bahwa informasi keuangan suatu organisasi dalam suatu periode yang menjabarkan kinerja dari organisasi tersebut. Laporan keuangan tersebut dianggap sangat penting untuk dibuat karena dapat menggambarkan kinerja organisasi dalam suatu periode.

\section{METODE PENELITIAN}

Jenis dan sumber data. Jenis penelitian yang digunakan dalam penelitian ini adalah penelitian kualitatif, yaitu metode yang sifatnya menguraikan, menggambarkan, suatu data dan keadaan serta menerangkan suatu keadaan sedemikian rupa sehingga ditarik suatu kesimpulan. Data primer adalah data yang diperoleh dari responden melalui kuesioner, kelompok fokus, dan panel, atau juga data hasil wawancara peneliti dengan narasumber. adalah :

Teknik pengumpulan data. Teknik yang penulis gunakan dalam penelitian ini

1. Wawancara, yaitu teknik pengmpulan data yang dilakukan dan diperoleh dengan mengadakan tanga jawab langsung dengan bagian-bagian yang berkepentingan dan terlibat langsung dengan masalah yang dibahas dalam penelitian ini.

2. Observasi, dimana peneliti akan melakukan pengamatan langsung keobjek penelitian untuk mendapatkan dan mencatat data-data yang diperlukan untuk penelitian.

3. Dokumentasi, dimana penelitian ini dimaksudkan untuk mendapatkan data yang dimaksud baik teori dan laporan keuangan yang ada di objek yang diteliti.

Metode analisa data. Metode yang digunakan adalah metode deskriptif yaitu dengan mengumpulkan data, menyusun, yang selanjutnya menginterpretasikan dan menganalisis dengan mengolah kembali data yang telah diperoleh sehingga memberikan keterangan yang lengkap mengenai masalah yang dihadapi.

\section{HASIL PENELITIAN DAN PEMBAHASAN}

\subsection{Hasil Penelitian}

Dasar Pelaporan Keuangan SMK Negeri 1 Manado. SMK Negeri 1 Manado belum menerapkan PSAKNo. 45 tentang pelaporan keuangan entitas nirlaba. Laporan keuangan SMK Negeri 1 Manado masih berbentuk neraca saldo. SMK Negeri 1 Manado mengeluarkan laporan keuangannya (neraca saldo) setiap bulannya. Rekening-rekening yang ada di Sekolah SMK Negeri 1 Manado berupa Rekening Kas, Perlengkapan, Peralatan, serta Pendapatan dan biaya-biaya yang terjadi di Sekolah SMK Negeri 1 Manado, Pendapatan yang diperoleh dari Subsidi-subsidi serta sumbangan dari para donator (komite sekolah). Pendapatan Subsidi didapat dari Bantuan Operasional Sekolah (BOS). Sementara itu biayabiaya yang dikeluarkan seperti pembayaran biaya-biaya untuk gaji guru honor, penjaga sekolah, biaya kebersihan sekolah, biaya telepon fax dan internet, pembelian peralatan kantor (ATK) dan biaya-biaya lainnya.

\subsection{Pembahasan}

Berdasarkan data transaksi diatas penulis akan membuat suatu Desain Akuntansi Sekolah SMK Negeri 1 Manado, yang merupakan Organisasi Nirlaba, agar penerapan akuntansi ini selanjutnya dapat menjadi bahan pembelajaran untuk organisasi nirlaba, khususnya organisasi nirlaba SMK Negeri 1 Manado. 
1. Kebijakan Akuntansi

a. Transaksi yang terjadi setiap harinya di SMK Negeri 1 Manado harus di catat dalam Jurnal Umum, yang selanjutnya di posting dalam Buku Besar, kemudian Neraca Saldo dan yang terakhir yaitu dilaporkan dalam Laporan Keuangan.

b. Laporan Keuangan SMK Negeri 1 Manado terdiri dari 4 laporan, yaitu : Laporan posisi Keuangan, laporan Aktivitas, laporan Arus Kas, dan Catatan Atas Laporan Keuangan.

c. Laporan Arus Kas dibuat dengan menggunakan metode langsung.

d. Metode pencatatan yang digunakan yaitu metode pencatatan berbasis akrual.

2. Pengakuan

a. Pengakuan pendapatan. Pendapatan sudah diakui walaupun Kas belum diterima.

b. Pengakuan Biaya. Pengakuan Biaya dilakukan pada saat kewajiban membayar sudah terjadi. Biaya telah diakui walupun biaya tersebut belum dibayar.

3. Pengukuran. Pengukuran dilakukan sesuai dengan nilai nominal dalam semua transaksi yang ada di Sekolah SMK Negeri 1 Manado.

4. Pelaporan yang diusulkan untuk Sekolah SMK Negeri 1 Manado adalah pelaporan berdasarkan Pernyataan Standar Akuntansi Keuangan Nomor 45 yaitu : Laporan Posisi Keuangan di setiap pelaporan akhir periode, laporan Aktivitas, laporan Arus Kas, dan Catatan atas Laporan Keuangan. Dengan pembuatan Laporan Keuangan berdasarkan PSAK no 45, diharapkan pihak SMK Negeri 1 Manado dapat memperoleh manfaatnya yaitu dapat lebih mudah mengatur pengelolaan keuangan yang ada di SMK Negeri 1 Manado.

5. Penerapan akuntansi berdasarkan PSAK 45 yang dibuat untuk menjadi rekomendasi bagi SMK Negeri 1 Manado.

Setelah selesai membuat Neraca Saldo dan Neraca Saldo yang seimbang sisi debet dan kreditnya, selanjutnya bagian keuangan SMK Negeri 1 Manado membuat Laporan Keuangan yang terdiri dari 4 laporan yaitu : Laporan Posisi Keuangan, Laporan Aktivitas, Laporan Arus Kas, dan Catatan Atas Laporan keuangan. Pelaporan yang di desain untuk menjadi rekomendasi sekolah SMK Negeri 1 Manado.

1. Laporan Posisi Keuangan. Di dalam akuntansi keuangan, Neraca atau laporan posisi keuangan adalah bagian dari laporan keuangan suatu entitas yang dihasilkan pada suatu periode akuntansi yang menunjukkan posisi keuangan tersebut pada akhir periode tersebut. Neraca biasanya disusun pada periode tertentu, misalnya 1 tahun. Namun neraca juga dapat dibuat pada saat tertentu untuk mengetahui kondisi perusahaan saat ini bila diperlukan Setiap perusahaan diharuskan untuk menyajikan laporan keuangan dalam bentuk neraca Laporan ini dibuat dengan cara melihat urutan yang paling likuid antara Aktiva dan Pasiva, selanjutnya keduanya harus seimbang jumlah Aktiva harus seimbang dengan jumlah Pasiva.

2. Laporan Aktivitas. Laporan ini dibuat dengan cara menyusun pendapatan yang diterima dengan biaya-biaya yang dikeluarkan oleh SMK Negeri 1 Manado, selanjutnya jumlah Pendapatan akan dikurangi dengan jumlah biaya-biaya sehingga hasil akhirnya adalah jumlah Aktiva Bersih.

3. Laporan Arus Kas. Laporan Arus Kas yang di buat untuk SMK Negeri 1 Manado adalah Laporan Arus Kas dengan menggunakan metode langsung, cara pembuatan Laporan Arus Kas yaitu dengan menggelompokan rekening-rekening atau akun-akun yang masuk dalam aktivitas operasi,aktivitas investasi, dan aktivitas pendanaan.

4. Catatan Atas Laporan Keuangan. Catatan atas Laporan Keuangan merupakan salah satu unsur laporan keuangan yang menyajikan informasi tentang penjelasan atau daftar terinci atas nilai suatu pos yang disajikan dalam Laporan Realisasi Anggaran, Neraca, dan Laporan Arus Kas juga dalam catatan ini di buat untuk membantu pembuatan 
Laporan Keuangan yang ada. Laporan ini dibuat dengan cara menyusun pendapatan yang diterima dengan biaya-biaya yang dikeluarkan oleh SMK Negeri 1 Manado, selanjutnya jumlah Pendapatan akan dikurangi dengan jumlah biaya-biaya sehingga hasil akhirnya adalah jumlah Aktiva Bersih. Dalam pengertian yang lain Catatan atas Laporan Keuangan juga dapat membantu menjelaskan perhitungan item tertentu dalam laporan keuangan serta memberikan penilaian yang lebih komprehensif dari kondisi keuangan perusahaan. Catatan atas Laporan Keuangan dapat mencakup informasi tentang hutang, kelangsungan usaha, piutang, atau informasi kontekstual untuk menjelaskan angka-angka keuangan.

\section{KESIMPULAN DAN SARAN}

\subsection{Kesimpulan}

Berdasarkan hasil penelitian yang telah dilakukan di sekolah SMK Negeri 1 Manado dapat simpulkan bahwa penyusunan laporan keuangan di SMK Negeri 1 Manado belum menerapkan penyusunan laporan keuangan sesuai dengan format keuangan nirlaba yang terdapat dalam PSAK No.45.

\subsection{Saran}

Untuk meningkatkan kualitas laporan keuangan di SMK Negeri 1 Manado diharapkan untuk menerapkan laporan keuangan sesuai dengan PSAK No. 45 pada laporan keuangannya agar memiliki laporan keuangan yang berkualitas.

\section{DAFTAR PUSTAKA}

Dinanti, A., \& Nugraha, G. A. (2018). Pelaporan keuangan organisasi nirlaba. Jurnal Ekonomi, Bisnis dan Akuntansi (JEBA), 20(01). http://jp.feb.unsoed.ac.id/index.php/jeba/article/view/1081

Hans, K. (2016). Akuntansi Keuangan Berdasarkan SAK Berbasis IFRS Buku 1. Jakarta: Salemba Empat.

Helen, K. (2017). Ciri-ciri dan standar akuntansi perusahaan nirlaba. https://www.jurnal.id/en/blog/2017-ciri-ciri-dan-standar-akuntansi-perusahaannirlaba/

Jimmy, G. (2014). A to Z Human Capital (Manajemen Sumber Daya Manusia). Jakarta: Penerbit Grasindo.

Januarizal, R. (2013). Organisasi profit dan non profit http://dephumsflow.blogspot.co.id/2011/09/organisasi-profit-dan-organisasi-non.html

Korompis, C (2014). Penerapan PSAK No. 45 Tentang Pelaporan Keuangan Organisasi Nirlaba Pada Sanggar Seni Budaya Logos Ma'Kantar. Going Concern : Jurnal Riset Akuntansi, 9(3), 52-60. https://doi.org/10.32400/gc.9.3.6124.2014

Munawir, S. (2016). Analisis Laporan Keuangan Edisi keempat. Cetakan kelima belas. Yogyakarta : Liberty

Nugroho, I. (2012). Penerapan Akuntansi Pada Usaha Mikro Kecil Dan Menengah (UMKM). JMK, 10(2). https://www.academia.edu/36891970 diakses hari sabtu 20 juli 2019

Andarsari, P. R. (2016). Laporan Keuangan Organisasi Nirlaba (lembaga Masjid). Ekonika : Jurnal Ekonomi Universitas Kadiri, 1(2), 143-152. http://dx.doi.org/10.30737/ekonika.v1i2.12

Warren \& Reeves. 2013. Pengantar Akuntansi Adaptasi Indonesia (Buku 1). Diterjemahkan oleh : Damayanti Dian. Jakarta : Salemba Empat

Tinungki, A. V. M., \& Pusung, R. J. (2014). Penerapan laporan keuangan organisasi nirlaba berdasarkan PSAK No.45 pada Panti Sosial Tresna Werdha Hana. Jurnal Riset 
Mario Rantung, Harijanto Sabijono, Victorina Z. Tirayoh

Ekonomi dan Bisnis, $\quad$ Akuntansi, $2(2), \quad 809-819$.

https://ejournal.unsrat.ac.id/index.php/emba/article/view/4417 